\title{
The Art of Resistance in the Palestinian Struggle Against Israel
}

\author{
Eray Alım*
}

\begin{abstract}
This manuscript aims to assess Palestinian street art's effectiveness as a resistance tool and political instrument in the struggle waged against Israel. It concludes by employing Bourdieu's concept of symbolic power that Palestinian street art is an effective instrument on account of its ability to instill in Palestinian collective consciousness as a sense of resistance. By utilizing Mouffe's definition of politics as being a constant struggle between hegemonic and counter hegemonic forces, this work also holds that street art serves Palestinians as a means to reaffirm their political existence and develop an alternative political imagination against the Israeli-imposed reality. This manuscript also broaches the oft-discussed issue of visual diversity in Palestinian street art scene and concludes that eclectic content may serve as a contributive force, if the counter hegemonic character of Palestinian street art is adhered to.
\end{abstract}

Keywords: Street Art, Palestine, Israel, Resistance, Politics

Assistant Professor, Batman University, TR, Department of Political Science and Public Administration, orcid.org/0000-0001-7543-8021, erayalim@hotmail.com 


\title{
İsrail'e Dönük Filistin Mücadelesinde Direniş Sanatı
}

\author{
Eray Alım*
}

\section{Öz}

Bu makale İsrail'e karşı yürütülen mücadelede Filistin sokak sanatının bir direniş unsuru ve siyasi enstrüman olarak etkisini değerlendirmektedir. Bourdieu'nün sembolik güç kavramından yararlanılarak, sokak sanatının Filistin kolektif bilincine direniş duygusu aşılamada etkili bir araç olduğu vurgulanmaktadır. Ayrıca Mouffe'un, siyaseti, hegemonik ve karşı hegemonik güçler arasında bir mücadele olarak tanımlamasından hareketle, sokak sanatının Filistinlilere siyasi olarak var olduklarını yineleme ve İsrail'in empoze ettiği gerçekliğe karşı alternatif bir politik tahayyül ortaya koymada etkin bir enstrüman olarak hizmet ettiği belirtilmektedir. Bu makalede sıklıkla tartışılan bir konu olan görsel çeşitlilik mevzusu da ele alınmakta ve eklektik içeriğin, Filistin sanatının karşı-hegemonik karakterine uyumlu olduğu sürece katkı sağlayabileceği savunulmaktadır.

Anahtar Kelimeler: Sokak Sanatı, Filistin, İsrail, Direniş, Politika

* Dr. Öğr. Üyesi, Batman Üniversitesi, TR, Siyaset Bilimi ve Kamu Yönetimi, orcid. org/0000-0001-7543-8021, erayalim@hotmail.com 


\section{Introduction}

The Israeli-Palestinian conflict is one of the longest protracted conflicts in the world. It rests on a dispute arising from competing claims by two nations over the same piece of land. The United Nations Partition Plan for Palestine in 1947 and Israel's declaration of independence in following year set the stage for the beginning of a serious territorial dispute. This dispute also set Israel on a collision course with its Arab neighbours, thus generating broader geopolitical consequences. Although the Arab-Israeli conflict has significantly subsided mostly due to Israel's signing of peace treaties with Egypt and Jordan, the Israeli-Palestinian problem continues, with Palestinians having to endure Israel's occupation of the West Bank and blockade of the Gaza Strip. The unresolved territorial problem provides a breeding ground for clashes and skirmishes between the two sides, indicating the unsustainability of the Israeli-imposed status quo. Nevertheless, Israel has been persistent in maintaining it, which is most evident in its annexation policy in the West Bank, which undermines the prospect for a two-state solution. ${ }^{1}$

Despite facing considerable difficulties in the face of a more powerful opponent, Palestinians have shown a remarkable degree of resilience in their determination to subvert the Israeli-imposed order and restore their sovereignty. Over the course of years, they have employed various means of resistance and methods of struggle in the pursuit of claiming their inherent rights on the historic Palestinian land. These included armed resistance, civil disobedience and attempts to internationally isolate Israel. During their struggle, Palestinians have come to acknowledge the importance of

Numerous officials and experts have expressed this concern including U.S policymakers. See, for example: Nathan Thrall, The Only Language They Understand: Forcing Compromise in Israel and Palestine (New York: Metropolitan Books, 2017, Kindle Edition), 3047-3071. U.S leaders also occasionally called for the necessity of the creation of "a viable Palestinian state". Husam Mohamad, "President George W. Bush's Legacy on the Israeli-Palestinian "Peace Process"", Journal of International and Area Studies 22, no. 1 (2015): 83. Cognizant of the fragile status quo, U.S policymakers such as those served in the George H. W. Bush administration engaged in "evenhanded" diplomatic initiatives to help realize a sovereign Palestinian state. Avi Shlaim, The Iron Wall: Israel and the Arab World (Updated and Expanded) (New York: W. W. Norton \& Company, Kindle Edition, 2014), 771. The reason for highlighting these points is to emphasize that, being Israel's staunchest allies, U.S policymakers are aware of the necessity of Palestinians having their own sovereign state, which is a telling indictor of the unsustainability of the status quo. 
creating and spreading awareness about life under occupation, and this has required representing their grievances in a way that both local and international actors get a clear understanding of their circumstances. To this end, they have engaged in the practice of constructing visual illustrations, through which to communicate their experiences under the Israeli-enforced politico-military system. Since the First Intifada, creating visual depictions to describe and reflect upon various aspects of the Palestinian problem has become a common exercise. ${ }^{2}$

If one were to embark upon an analysis of this exercise, one would need to place a special emphasis on street art, as it has a central place in Palestinian resistance and serves as a key instrument in Palestinian civic and political activism. As will be detailed in this work, street art's main utility lies in its functionality as a medium through which Palestinians reiterate their commitment to bring an end to the occupation. By filling the public space with counter hegemonic visual narratives, Palestinians convey to the Israeli authorities their tenacity and perseverance towards their rights and aspirations. Among its functions, street art acts as a force multiplier for Palestinians, since artworks depicting Palestinian cause serve to stimulate collective emotions and imbue Palestinians with a feeling of togetherness. Especially historically meaningful symbols and icons suffusing street artworks instill in Palestinians a feeling of resistance as well as a determination of struggle. Over the course of more than three decades, street art has remained an indispensable element of Palestinian

Intifada denotes two mass-scale Palestinian uprisings against Israel. Although the protest movements began spontaneously, they morphed into unprecedented revolts and lasted several years until they fizzled out. The First Intifada, symbolized by the use of rocks by Palestinians, began in 1987 after Israeli security forces' killing of four Palestinian youth and lasted until the time of the signing of the Oslo agreement in 1993. The Second Intifada occurred as a result of Ariel Sharon's visit to Temple Mount in 2000. The visit set off waves of Palestinian protests on the grounds that Sharon's visit signalled Israel's intention to seize Temple Mount, which also houses the Al-Aqsa mosque. The Second Intifada, organized by Hamas, withered away following the death of Palestinian National Authority leader Yasser Arafat in 2004. Although both events involved violent scenes, the Second Intifada singled itself out due to the use of methods such as suicide bombings and armed resistance. Given this background, the prospect of the emergence of a third Intifada constitutes a significant risk. The elimination of this risk, though, is fraught with difficulties given the persistence of Palestinian-Israeli conflict. Lee Williams, "Intifada: What Is It - and What Does a Third Uprising Mean for the Region?". The Independent, October 9, 2015, https://www.independent.co.uk/ news/world/what-exactly-is-an-infitada-a6688091.html. 
resistance as well as an influential instrument to reaffirm Palestinians' political existence.

This work seeks to outline the main characteristics of Palestinian street art through an assessment of its effectiveness in two thematic contexts. It examines street art's function as a tool of resistance and as a political instrument in the Palestinian struggle against Israel. By focusing on visuals created by different Palestinian groups as well as international artists, this article also addresses how visual diversity within the Palestinian street art scene influences street art's effectiveness. Taking street art as a site of analysis requires an evaluation of artworks associated with the Palestinian culture of resistance. This shall be done through the method of visual case study. Visual case selection has been made on the basis of visuals' explanatory potential to reflect upon and elucidate Palestinian life under occupation. The 12 graffiti images chosen to this end also include pictures produced by foreign artists, the purpose being to provide an empirical context for a discussion on the utility of international contribution to Palestinian visual resistance. Conceptually, Pierre Bourdieu's notion of symbolic power and Chantal Mouffe's definition of politics as being a struggle between hegemonic and counter hegemonic forces will be employed to establish the required complementarity between art, resistance and politics. This article starts by offering a brief historical overview of art in Palestine and then moves on to analyzing Palestinian street art in relation to resistance, politics and visual diversity.

\section{Art in Palestine: A Historical Background}

The roots of the Israeli-Palestinian conflict lie in the late $19^{\text {th }}$ century, which witnessed the first attempts to create a Jewish state on the historical land of Palestine. The ideological underpinning of this political project was Zionism, whose adherents considered it essential to secure a national land for Jews. ${ }^{3}$ Despite traumatic episodes experienced by Jews such as the

Zionism originated as a modern secular movement at the end of the $19^{\text {th }}$ century, with the First Zionist Congress, held in 1897, marking the beginning of the movement. Although a controversial term due to its alleged discriminatory character vis-à-vis Palestinians, the label "Zionism" was adapted by Jews themselves, evident in the name of "Zionist Congress". From the outset, Zionism was in tension with competing ideological approaches espoused by Jews of religious background. Although both 
pogroms of the early $20^{\text {th }}$ century, in the eyes of the early Zionist leaders, security-related reasons were subordinate to the overall of objective of holding together the Jewish nation. Historian Zeev Sternhell argues that, as Zionist leaders "saw it, Zionism was an operation to rescue the nation and not an operation to rescue Jews as individuals. For them, the quantitative aspect was always secondary." "Despite prioritizing the qualitative dimension of preserving the essence of the Jewish nation, the process initiated by Zionist leaders to establish a Jewish homeland paved the way for the influx of Jews into historic Palestine, which received more than half a million immigrants between 1882 and $1948 .{ }^{5}$ With this inflow, social and demographic makeup of Palestine underwent significant changes, which also signaled the prospect of the political division of the country along ethnic lines.

In the course of realizing the Zionist project of creating a nation-state, one of the first attempts by the new authorities was to build a Jewish art scene, which was geared towards the goal of strengthening national spirit. ${ }^{6}$ The broad objective was to represent the territorial space in a way that would reinforce the Zionist political imagination. This imagination manifested itself in places like Jerusalem, where, for example, architectural decorations were undertaken in accordance with political as well as visual/aesthetic requirements. The use of "stone cladding", for instance, was oriented towards the goal of preserving and projecting Jerusalem's holiness. ${ }^{7}$ And this was tied into the political objective of laying greater claim on the city. As Weizman notes, "When the city itself is perceived to be holy, and when

religious and secular Jews converged on the goal of strengthening Jewish presence in Palestine, they diverged on the ideological motif of their struggle. Whereas secular Zionists' purpose was to establish a secular nation-state on Palestinian land, "pre-Zionist" Jewish population was "deeply hostile to the notion of secular Jewish autonomy in the Holy Land, which, according to religious doctrine, would be redeemed only through divine intervention in the messianic age." Tom Segev, One Palestine, Complete, Trans. Haim Watzman (New York: Metropolitan Books, 2000), 16-17.

4 Zeev Sternhell, Nationalism, Socialism, and the Making of the Jewish State, trans. David Maisel (Princeton: Princeton University Press, 1998), 51.

5 Gilbert Achar, The Arabs and the Holocaust: The Arab-Israeli War of Narratives (London, Saqi Books, 2010), 18.

6 Dalia Manor, Art in Zion: The Genesis of Modern National Art in Jewish Palestine (London: Routledge, 2005), 1.

7 Eyal Weizman, Hollow Land: Israel's Architecture of Occupation (London: Verso, 2007), 28-32. 
its boundaries are flexibly redrawn to suit ever-changing political aims, holiness inevitably become a planning issue." 8 As will be discussed below, attempts were also made for the construction of meaningful symbols in order to achieve favorable visualizations of the newly-settled territories.

An analysis of the motivation of new settlers in constructing visual depictions requires stressing that it mostly had to do with "ethnographic as well as imperialist mentality." ${ }^{\circ}$ For instance, following their invasion of new lands and defeat of enemies, Roman, Egyptian and Assyrian empires sought to portray and convey a triumphant image of themselves through the creation of reliefs and epigraphs. ${ }^{10}$ The practice of producing visual illustrations for a similar purpose was also adopted by modern political units. Including totalitarian movements, they employed, along with paintings, techniques such as cinema and photography in their attempts to conduct mass propaganda and construct favorable visual narratives of themselves. ${ }^{11}$ The overall purpose was to create depictions of political landscapes, which they sought to dominate, in a way that reflected their own imaginations and aspirations. Art in its various forms, then, served as a potent communicative medium for modern political authorities.

As a product of modernity, Zionist ideology employed a similar set of practices in Palestine in the early $20^{\text {th }}$ century. During this period, the fifth Zionist Congress, organized in 1901, marked the first attempt to create a Jewish national art. Although some intellectuals present in the Congress rebuffed the idea of creating a Jewish art, "the Jewish thinker and writer Martin Buber" argued that the objective could be achieved, but on the condition that a Jewish national homeland is secured. ${ }^{12}$ This perspective was in line with the vision of Boris Schatz, who would come to play a pivotal role in the entrenchment and growth of Jewish art in historic Palestine. Subsequently, with the start of Jewish migration to Palestine,

Weizman, Hollow Land, 33.

Michael J. Shapiro, Methods and Nations: Cultural Governance and the Indigenous Subject (London: Routledge, 2004), 174.

10 David D. Perlmutter, "Photojournalism and Foreign Affairs," Orbis 49, no. 1 (2005): 112.

11 Perlmutter, "Photojournalism and Foreign Affairs," 113; Shapiro, Methods and Nations, 135.

12 Manor, Art in Zion, 1-2. 
adherents of Zionism set out to design an institutional structure for the growth and development of an artistic life in their would be homeland.

The most important development during this period was the establishment of the Bezalel School of Arts and Crafts in Jerusalem in 1906. Its founder Boris Schatz had been hailed by art historians for laying the groundwork for art to flourish "in a country which was barren, desolate and primitive."13 The negative depiction of Palestine through the use of adjectives such as "primitive" can be argued to be aimed at generating the perception that this barren land had to be developed, which, among other things, would necessitate the creation and promotion of a Jewish national art. Given this objective, for art historians, the creation of an institution like Bezalel was "the realisation of a dream or a utopia." 14 In view of the importance of setting up an art foundation in Palestine, spear headers of the Zionist movement provided the wherewithal for Jewish national art to take root and flourish. A clear indication of this is that Belazel "was founded and funded by the Zionist Organisation" 15

As opposed to the negative depiction of Palestine, there was a vibrant social existence, which, among various indicators, was evident in the cultural atmosphere that informed Palestinian artistic life. A brief glimpse into the historical trajectory of Palestinian art would show that the art movement in the country was initially under the influence of Arab Christian iconography, which dominated the art scene until the late $19^{\text {th }}$ century. During this period, religious themes were the central features in Palestinian art, but visual elements representing local Arab culture had also been present in paintings. ${ }^{16}$

Following their seizure of Palestine, when Ottoman authorities set out to install Greek-church patriarchs with the aim of transforming Arab churches in accordance with their own vision, Palestinians countered this move by Arabizing their icons. This was an attempt at preserving their

\section{Ibid., 3.}

14 Ibid.

15 Ibid.

16 Joseph Massad, "Permission to Paint: Palestinian Art and the Colonial Encounter," Art of Journal 66, no. 3 (2007): 128. 
indigenous iconography and resisting the hybridization of their culture. ${ }^{17}$ In the following period, when Palestinian art took on a more secular style, which characterized the period from late $19^{\text {th }}$ century to 1948 , artists such as Nicola Saig, Khalid Halabi and Mubarak Sa'ed left their imprint on the art scene with their impressive paintings. ${ }^{18}$ During this phase, Palestinian art was also represented in the Jerusalem art fair called the First National Arab Fair by the Palestinian artist Zulfa el-Sa'di. ${ }^{19}$ Regarding the thematic focus of Palestinian artworks, paintings mostly revolved around issues related to "identity, memory, location, and resistance." ${ }^{20}$ Artworks depicting Palestinian life also included a repertoire of "politically potent icons like the cactus and metaphors such as Palestine as motherland." ${ }^{21}$ With their embodiment of emblematic symbols, paintings pre-1948 provide an insight into the indigenous Palestinian cultural and political existence.

As well as attesting to the existence of a Palestinian life prior to the Nakba, art activity in historic Palestine is indicative of Palestinians' sensitivity in preserving the cultural fabric of their society. Despite this sensitivity, cultural and artistic life in Palestine faced a formidable challenge in 1948, when a mass exodus known as the Nakba took place. Among the traumatic consequences of the Nakba was the loss of a cultural terrain for Palestinians. ${ }^{22}$ Due to forced displacement, artists were compelled to move to places such as Beirut, where some of them strove to perform art in refugee camps, under highly impractical conditions. ${ }^{23}$ Palestinian art faced another setback with Israel's winning of the Six Day War in 1967 and seizure of the West Bank and Gaza. This marked the beginning of significant practical difficulties for Palestinian artists and cultural enthusiasts due to Israel's implementation

$17 \quad$ Ibid., 128.

18 Miri Gal-Ezer, "The Third Space? From Modern Art Gallery to Modern Museum in Umm El-Fahem," in Memory and Ethnicity: Ethnic Museums in Israel and the Diaspora, ed. Emanuela Trevisan Semi, Dario Miccoli and Tudor Parfitt (New Castle: Cambridge Scholars Publishing, 2013), 125.

19 Gal-Ezer, "The Third Space?," 125.

20 Rhonda A. Saad, "Palestinian Art: From 1850 to the Present by Kamal Boullata," The Arab Studies Journal 18, no. 1 (2010): 331.

$21 \quad$ Ibid.

22 Kamal Boullata, “Art under Siege,” Journal of Palestine Studies 33, no. 4 (2004): 71.

23 Kamal Boullata, “Artists Re-Member Palestine in Beirut," Journal of Palestine Studies 32, no. 4 (2003): 25-30. 
of strict censorship practices. Restrictive measures included banning paintings bearing the colors of Palestinian flag, ${ }^{24}$ closing down galleries and arresting artists. ${ }^{25}$ Art exhibitions were closely monitored by Israeli authorities, who came to view them "as emblematic of a collective national identity and crucibles of defiant resistance to occupation."26

\section{Street Art as an Instrument of Resistance}

As the above account shows, Palestinian art holds a mirror to the political history of Palestine in general. Street art has joined the aforementioned historical context as a new artistic endeavor, whose main importance lies in its ability to serve Palestinians as an instrument of resistance against Israel. As emphasized above, due to the discomfort felt towards Palestinian artworks, Israeli authorities resorted to restrictive measures such as censorship and prohibition of exhibitions. Street art was subjected to a similar treatment, since it proved to be an effective communication apparatus especially during the First Intifada, enabling Palestinians to disseminate their messages under heavy security measures. ${ }^{27}$ During this period, graffiti "became a way to organize protests, strikes, and rallies; to affirm allegiances; to warn against collaboration; and finally, to demarcate political boundaries." ${ }^{28}$ To deter Palestinians from engaging in street art, Israeli security forces "used fines, imprisonment, and forced local youth to erase graffiti." ${ }^{" 29}$ In the following period, Israeli police engaged in activities such as teaming up with local Palestinian collaborators to remove the graffiti works it had considered troubling, mostly due to their evocation of the Nakba. ${ }^{30}$

24 Ashley Toenjes, "This Wall Speaks: Graffiti and Transnational Networks in Palestine," Jerusalem Quarterly 61 (2015): 57.

25 Boullata, "Art Under Siege," 72.

26 Ibid.

27 Toenjes, "This Wall Speaks," 56.

28 Craig Larkin, “Jerusalem's Separation Wall and Global Message Board: Graffiti, Murals, and the Art of Sumud," The Arab Studies Journal 22, no. 1 (Special Issue: Cultures of Resistance, 2014): 149.

29 Larkin, "Jerusalem's Separation Wall and Global Message Board,” 149.

30 Gawan Mac Greigair, "Nazareth's Mystery Mural as an Emblem of Palestinian Resistance," Al Araby, November 2, 2107, https://www.alaraby.co.uk/english/ indepth/2017/11/13/nazareths-mystery-mural-as-an-emblem-of-palestinianresistance. 
The resort to such measures begs the question that despite enjoying overwhelming superiority in hard-power capabilities vis-à-vis Palestinians, what drives Israel into a security-oriented approach towards Palestinian street art. As this work maintains, the recourse to heavy-handed measures by Israeli authorities attests to their recognition of the potential of street art to empower Palestinian resistance. Given that power is a fungible concept and that it may be as much material as immaterial, balance of power between Israel and Palestine presents a more complex picture than generally assumed. Cognizant of this complexity, Israeli authorities see a troubling aspect in artistic illustrations because of their ability to provoke a sense of struggle among Palestinians and stimulate alternative political imaginations.

Indeed, whether it is a simple drawing or an exquisite painting, artistic expressions can be highly influential instruments due to the "symbolic power" they possess. ${ }^{31}$ Bourdieu defines symbolic power as "an almost magical power, which enables one to obtain the equivalent of what is obtained through force, by virtue of the specific effect of mobilization." ${ }^{32}$ This definition aptly captures street art's potential in the context of Palestinian resistance, since, viewed through Bourdieu's lens, it has played an instrumental role in galvanizing the anti-occupation sentiment and acted as a catalyst for Palestinian mobilization. This was especially evident when there was no "national media, political assembly, or other elements of self-determination" and "graffiti was a way for Palestinians to transgress the censors and express political messages." ${ }^{33}$ During this period, graffiti images helped bolster Palestinian unity, and given their proven effectiveness, they have gradually become an inherent part of Palestinian discourse of resistance. According to De Certeau, "The credibility of a discourse is what first makes believers act in accord with it. It therefore produces practitioners. To make people believe is to make them act." ${ }^{\prime 3}$ Viewed through this lens, due to the impact they leave on collective consciousness, visual discourses also have the potential to make people act in accordance with the messages they aim to spread. Palestinian graffiti

\footnotetext{
31 Pierre Bourdieu, Language and Symbolic Power (Cambridge, Polity Press, 1991), 166.

32 Ibid.

33 Toenjes, "This Wall Speaks," 57.

34 Michel De Certeau, The Practice of Everyday Life (Berkeley: University of California Press, 1984), 148.
} 
images attest to the validity of this hypothesis, since, as will be elaborated below, they have acted as an effective medium to unite Palestinians around the same cause, while also helping them defy Israel's "cognitive imperialism." 35

In occupied Palestine, Israel has sought to achieve its cognitive imperialist objectives through "a visual language that was used to blur the facts of occupation and sustain territorial claims of expansion." ${ }^{\text {36 }}$ The growth of Israeli settlements in the West Bank has been accomplished through the visual transformation of the territorial landscape, which required projecting the settlements as "organic parts" of Israeli territories. ${ }^{37}$ The policy of designing the landscape based on the goal of expanding Israeli settlements led to the deterioration of Palestinian life, which is evident in the transition from occupation to cantonization and finally to separation. ${ }^{38}$

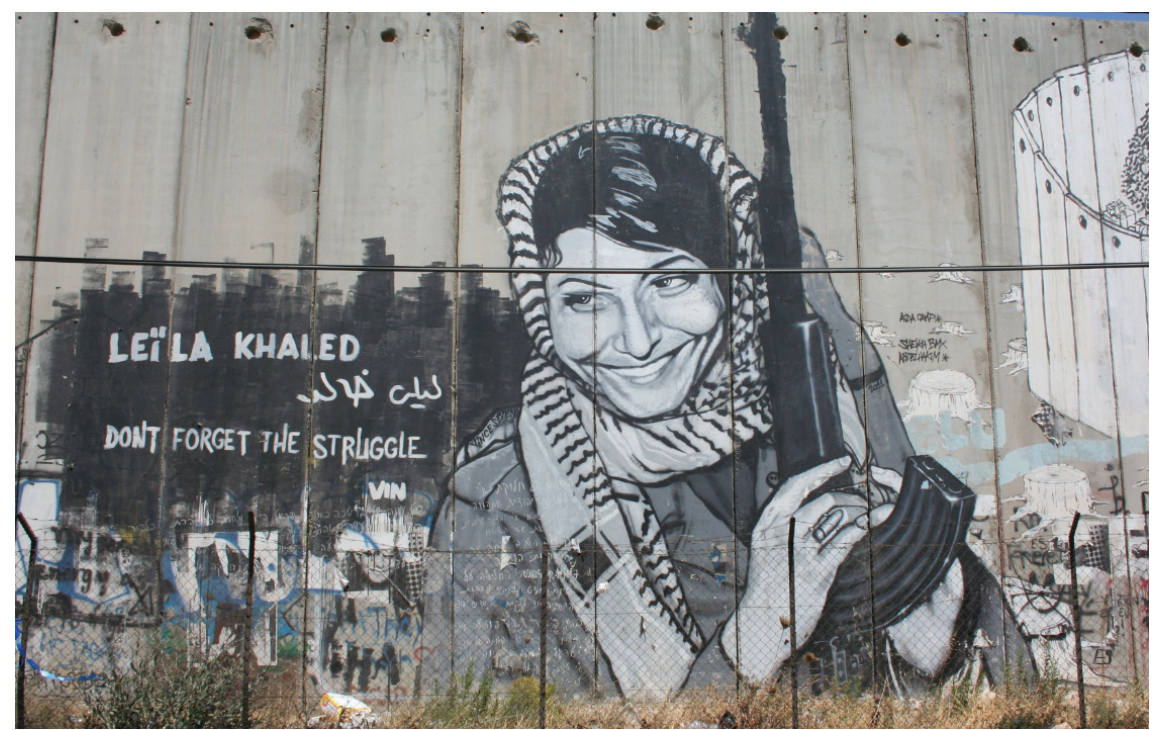

Figure-1: A mural of Leila Khaled on the Separation Wall

Image taken from: https://i.pinimg.com/originals/1c/da/3e/1cda3e9e4ae66257857007fcd108e53d.jpg

35 Shapiro, Methods and Nations, 29.

36 Weizman, Hollow Land, 26.

37 Ibid.

38 Samer Alatout, "Walls As Technologies of Government: The Double Construction of Geographies of Peace and Conflict in Israeli Politics, 2002-Present," Annals of the Association of American Geographers 99, no. 5 (2009): 956-68. 
Despite such unfavorable developments, Palestinians have proven resilient in their determination to continue resistance, for which street art has been an essential instrument. Palestinian visual acts involve attempts to undermine occupation by painting murals suffused with symbolically powerful images in public space. One of the most expressive graffiti images sketched on the walls in Palestine is a well-known image of the Palestinian militant Leila Khaled. Khaled is known as a "heroine and iconic figure"39 in Palestinian tradition of resistance. To counter Israel's attempts to portray Palestinian popular figures as terrorists, Palestinians have popularized one of Khaled's most remarkable images in their graffiti works. Khaled's image in Figure-1 indicates a facial expression that exudes hope and optimism and also "rejects the terrorist label." ${ }^{40}$ Although her smiling face can be construed as a sign of hope aimed for Palestinians, the image does not omit her militant self, which is signified by the keffiyeh and gun and is clearly aimed at Israel.

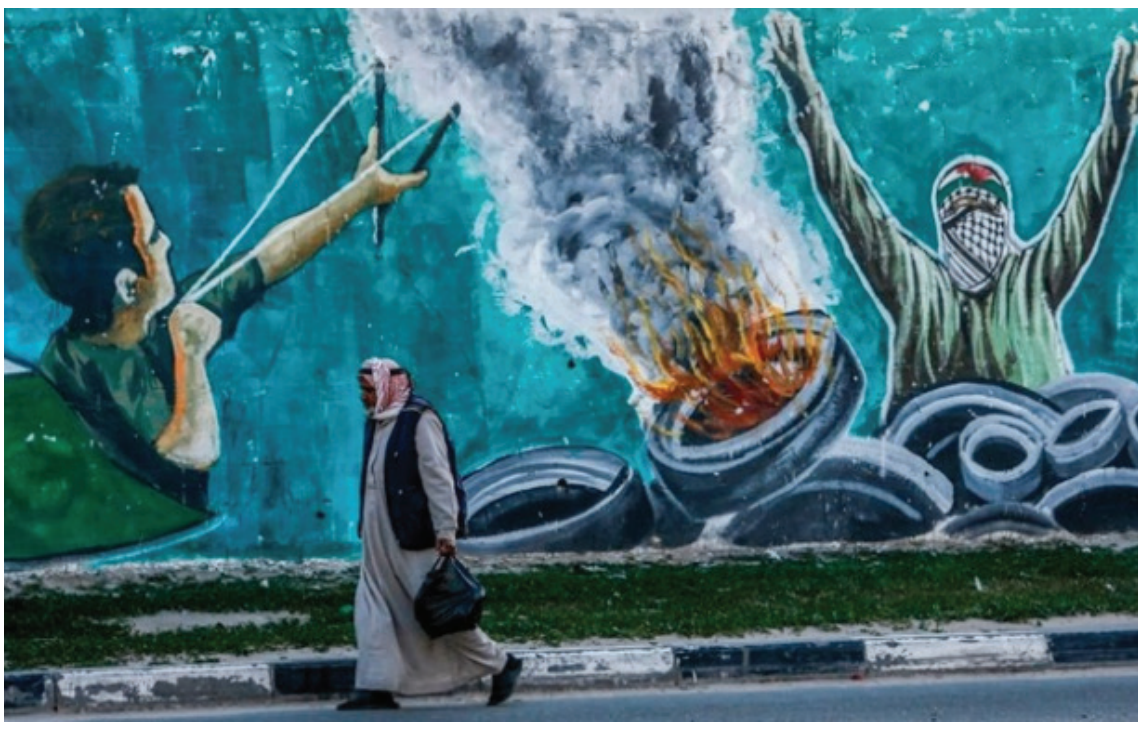

Figure-2: A mural depicting a resistance scene in Palestine

Image taken from: https://www.dailystar.com.lb/News/Middle-East/2019/Mar-15/478895-gaza-border-protestscalled-off-after-israel-air-raids-organizers.ashx

39 Laleh Khalili, Heroes and Martyrs of Palestine: The Politics of National Commemoration (New York: Cambridge University Press, 2007), 20.

40 Rebecca Gould, "The Materiality of Resistance: Israel's Apartheid Wall in an Age of Globalization,” Social Text 118 32, no. 1 (2014): 15. 
The Palestinian street art scene also features murals that depict the resisting Palestinian subject in the form of using a slingshot, burning tires or making a V-sign. Portraying these acts in a graffiti form, Figure-2 provides a powerful snapshot of Palestinian defiance and evidently conveys the message that circumstances necessitate resistance. As the acts depicted in Figure-2 represent gestures of resistance that are deeply rooted in the Palestinian struggle, such graffiti works also serve to refresh memories of liberation struggle.

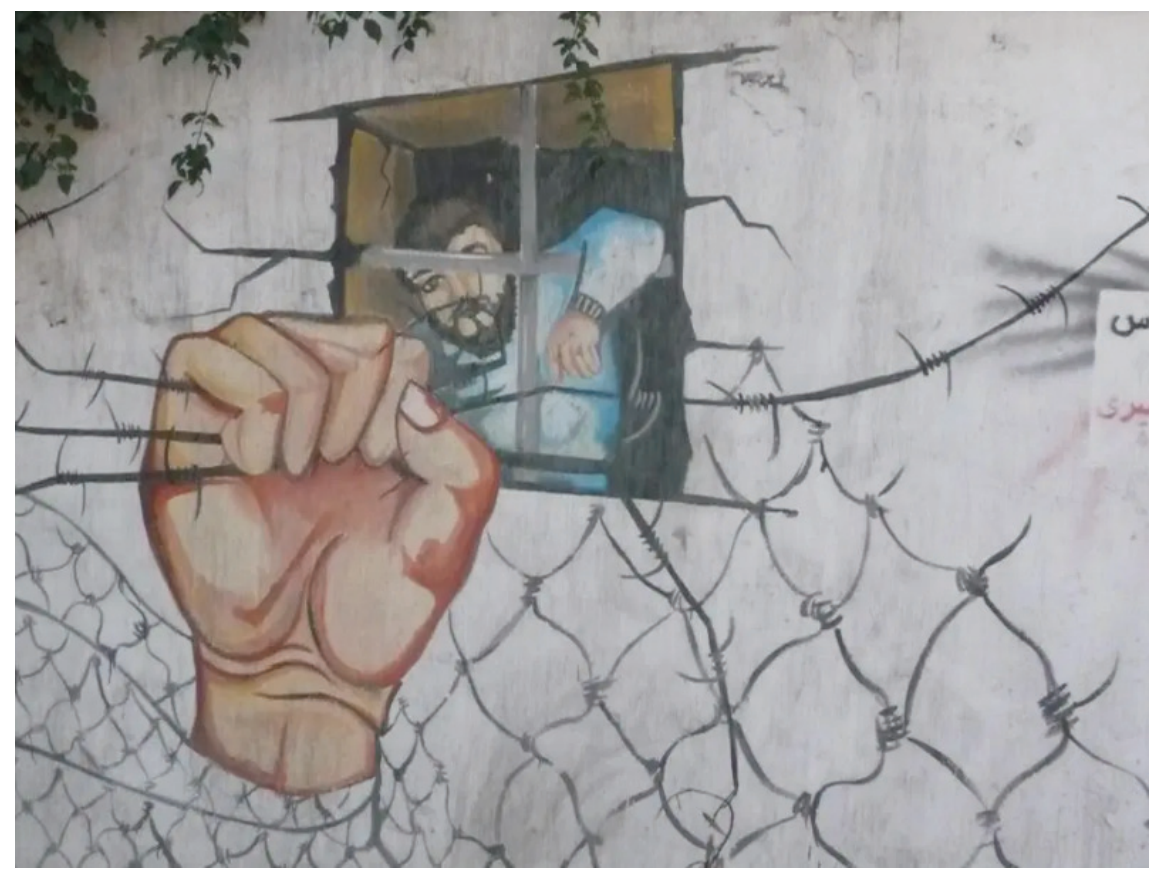

Figure-3: A hand on barbed wire image from Gaza

Image taken from: https://loralucero.wordpress.com/2012/12/18/\#jp-carousel-1428

Hand on barbed wire image is another symbolically effective illustration portraying Palestinian life under occupation. Israel's restriction of Palestinians' movement through the erection of barbed wire fences is often countered by Palestinians tearing down such barriers. The graffiti in Figure-3 illustrates this resistance act. Such graffiti images imbue Palestinian collective consciousness with a sense of togetherness, as they represent the common sentiment felt towards occupation. Perhaps the unifying function of street art in this context is best described by Baudrillard, who defines 
"graffiti signatures as "totemic" [...] symbols of group belonging and sentiment." ${ }^{11}$ From this perspective, graffiti images must be understood as devices that contribute to the emotional-motivational unity of Palestinians, despite the physical-territorial disunity that afflict their lives.

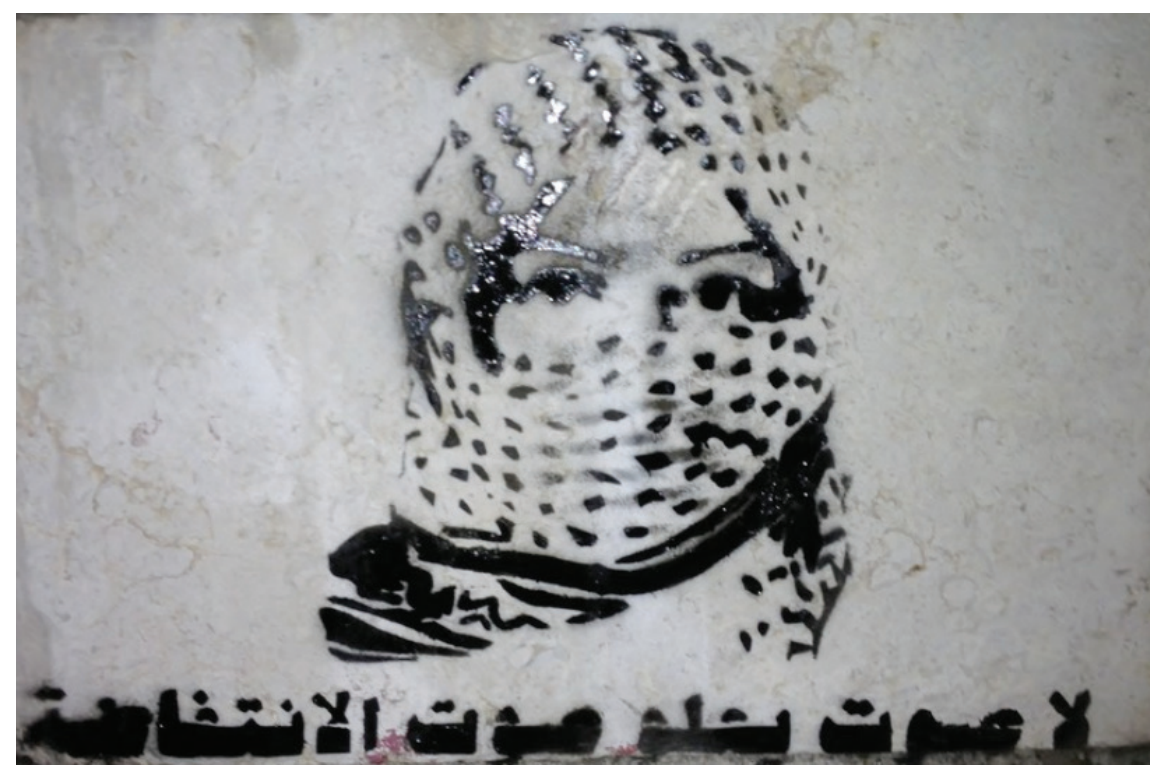

\section{Figure-4: The keffiyeh-clad woman}

"There's no voice greater than the voice of the intifada"

Image taken from: https://electronicintifada.net/content/taking-back-palestines-streets-exclusive-interview-undergroundjerusalem-graffiti-artist

Unity is most needed when acts of resistance are undertaken, and during such acts, graffiti is utilized as a tool to re-emphasize the existence of the defiant Palestinian subject. This is performed through Palestinian groups' imprinting of images of disobedience in public space. A case in point is an act that was held in 2012. During the act, Palestinians painted a keffiyehclad woman image "on the doors and walls of governmental buildings as well as the doorways of Israeli houses" in West Jerusalem and cities such as Haifa and Jaffa. ${ }^{42} \mathrm{~A}$ text accompanying the image, which reads "There's

$41 \quad$ Ibid., 149.

42 Maath Musleh, "Taking Back Palestine's Streets: Exclusive Interview with Underground Jerusalem Graffiti Artist," Electronic Intifada, August 29, 2012, 
no voice greater than the voice of the intifada" epitomizes the gist of the resistance that defined the visual campaign. The sporadic use of visuals that convey disobedience has the functional effectiveness of demonstrating to Israel the persistence of the Palestinian struggle.

As Israel holds overwhelming superiority in material capabilities, breaking Palestinians' will through dominance in power and making them accept the reality of occupation carry utmost importance. In the face of this, symbolically powerful images stimulate a sense of Palestinianness that rejects subordination. The functional importance of the above-shown iconic images lies in that they reflect outward into the lives of Palestinians and help produce practitioners of resistance. As emphasized by a Palestinian artist: "If you live in a conflict zone, anything can be used as a weapon [...] It's not killing, but it raises awareness. It's part of the fight." ${ }^{43}$ Through their engagement with street art, Palestinians acquire a means of revealing their commitment to overturning the status quo. Feelings of disobedience are often expressed by Palestinians such as Hassan Al-Abedi, a 55-yearold Palestinian farmer, who aimed his anger at the Israeli government by saying that "you will not break the Palestinians' will, you will never break our will, never, never." ${ }^{44}$ Street art is essentially an effective means of illustrating this decisiveness.

\section{Street Art as a Political Tool}

For a thorough assessment of Palestinian street art, its functionality as a political instrument also requires an analysis. Political history of Palestine can be described as a history of struggle waged through artworks and visual symbols. Following their migration to historic Palestine, Zionists sought to overcome the feeling of strangeness in their new land by redefining "in Jewish consciousness the meaning of 'being in the place' in contrast to the sense of displacement in the diaspora." ${ }^{45}$ And art contributed to the process

https://electronicintifada.net/content/taking-back-palestines-streets-exclusiveinterview-underground-jerusalem-graffiti-artist.

43 Hannah Jannol, "Banksy in the West Bank: Whose Art Is It Anyway?," The Jewish News of Northern California, July 13, 2018, https://www.jweekly.com/2018/07/13/ banksy-in-the-west-bank-whose-art-is-it-anyway/.

44 "Palestinians to Netanyahu: You Will Never Break Our Will," The Jerusalem Post, September 11, 2019, https://www.jpost.com/Israel-News/Palestinians-to-NetanyahuYou-will-never-break-our-will-601398.

45 Manor, Art in Zion, 125. 
of creating meaningful representations with a constellation of symbols associated with Jewish tradition. For example, Yaakov Stark's mural known as "the First Monumental Zionist Work of Art", located in Jerusalem's Ades Synagogue, served as a source of inspiration for "Zionism's visual language", since it is laden with historically meaningful signs and symbols such as "the Hebrew letters, the Star of David, the menorah, the flora of the land of Israel, the symbols of the Israelite tribes [and] the zodiac." ${ }^{46}$ Of these symbols, the Star of David and the menorah became the emblems of the new nation and Jewish sovereignty respectively. ${ }^{47}$ Stark's mural was followed by other artworks that contained a "repertoire of emblematic, idyllic and often non-specific images of the country as produced by Jewish artists in Palestine during the 1920s." 48 Attempts at constructing meaningful illustrations contributed to the constitution of the symbolic foundation of the soon to be established State of Israel.

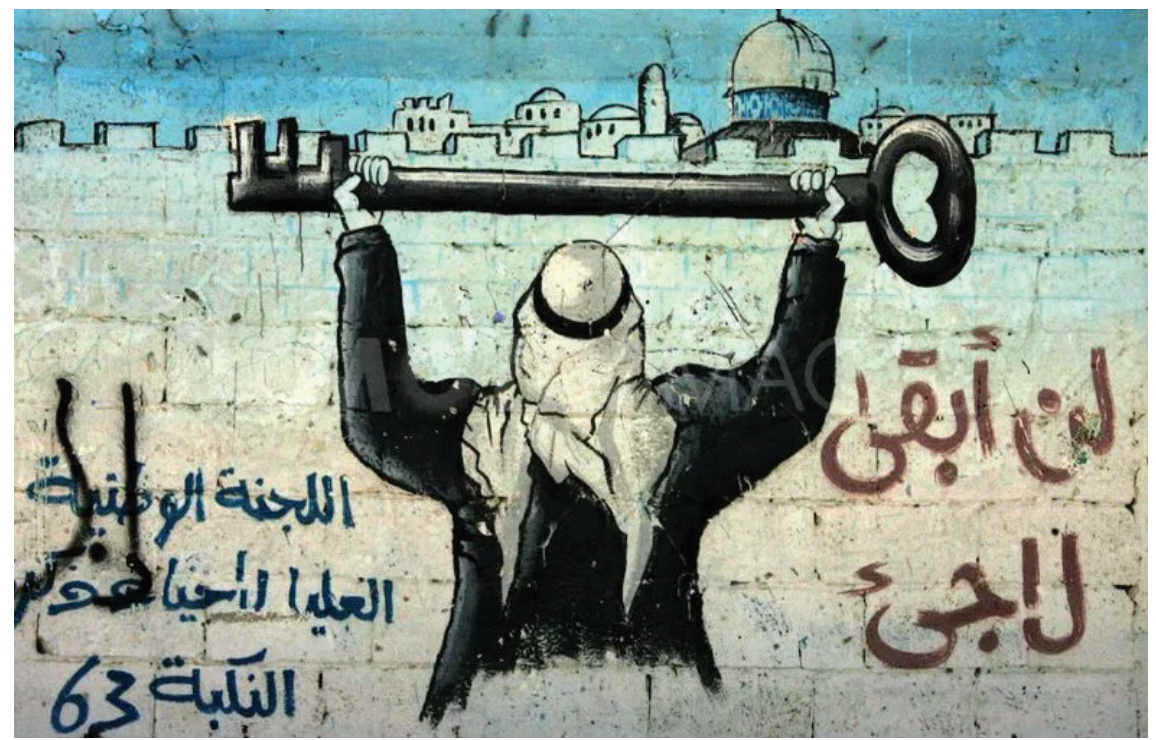

Figure-5: A mural bearing the key symbol

Image taken from: https://www.richardsilverstein.com/2018/01/21/case-palestinian-return/

46 Nir Hasson, "'First Monumental Zionist Work of Art' Uncovered in Jerusalem," Haaretz, October 15, 2012, https://www.haaretz.com/.premium-reviving-the-firstmonumental-zionist-artwork-1.5192847.

47 Ibid.

48 Manor, Art in Zion, 125. 
Given this background, Palestinians' attempts to build their own visual vocabulary must be viewed as an endeavor that is aimed at undermining Zionism's political imagination. Indeed, visual and textual elements populating Palestinian settings carry strong political overtones such that they reflect a determination to assert the Palestinian subject's political existence in connection with the broad goal of establishing a sovereign Palestinian statehood. Visual messages designed to convey Palestinian aspirations primarily stress Palestinians' dedication to recover their inherent rights over the historic land of Palestine. This is revealingly demonstrated by the key symbol. As well as signifying Palestinian uprootedness, this symbol is also representative of Palestinians' determination to acquire the right of return. As the right of return has been has been one of the most contentious issues between the Israeli and Palestinian sides, through their consistent use of the key symbol in their visuals, Palestinians continue to remind Israel that they remain steadfast in their commitment to reclaiming their land.

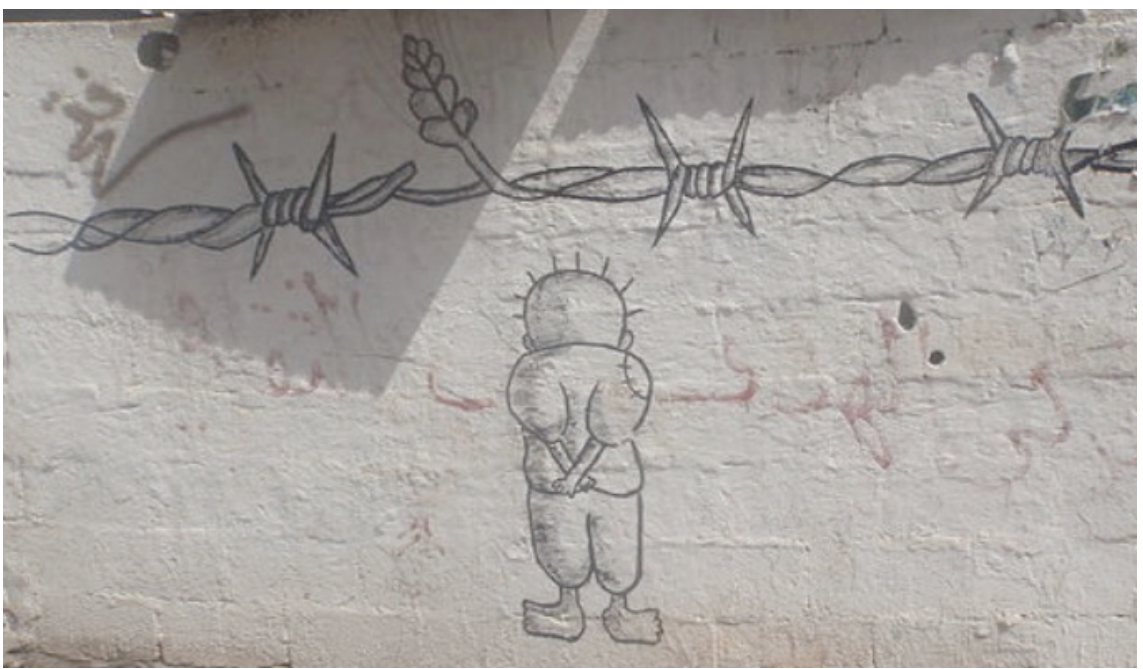

Figure-6: The Handala image

Image taken from: https:/972mag.com/the-palestinian-dilemma-between-ideology-and-reality/56131/

An equally powerful visual is the Handala image, created by the late Palestinian artist Naji al-Ali. ${ }^{49}$ The image depicts a disgruntled barefooted

49 Al-Ali's own story is a poignant portrayal of Palestinian uprootedness. Born in 1937, al-Ali was forced out of Palestine in 1948 and then ended up in a Lebanese refugee camp. With the help of the Palestinian author Ghassan Kanafani, al-Ali began to develop a career as a cartoonist and worked for various journals and newspapers in 
boy with his hands clasped behind his back and poignantly illustrates a child's sorrow occasioned by displacement. As stated by Al-Ali, the image reflects his own story, since he was forced to leave Palestine at the age of ten, like numerous other Palestinian children. ${ }^{50}$ As well as visually depicting Palestinian displacement, Handala also signifies Palestinian aspiration for justice. As Masalha stresses, "Handhala became a powerful icon of Palestine and the symbol of Palestinian refugee struggle for justice, return and liberation." ${ }^{51}$

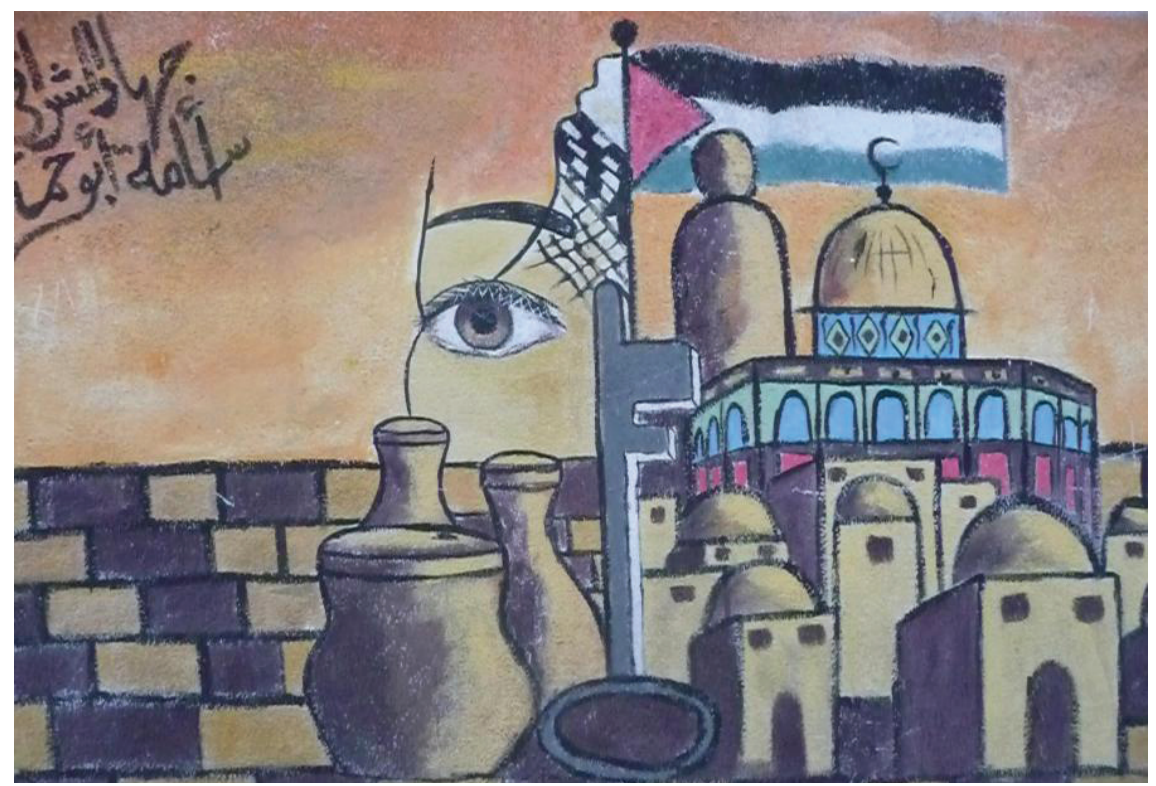

Figure-7: A mural bearing the images of the Palestinian flag, the key symbol and the Dome of the Rock

Image taken from: https://loralucero.wordpress.com/2012/12/18/\#jp-carousel-1428

Beirut and Kuwait. Moving back and forth between Lebanon and the Gulf during the Lebanese civil war, al-Ali finally ended up in London, where he was killed by unknown assailants in 1987. With a career spanning over three decades, al-Ali left an impressive collection of work of more than forty thousand cartoons. Al-Ali's most famous image Handala, as he describes it, is a "condensation of the pain, longing, and love experienced by millions of Palestinians and Arabs in the late twentieth century." Sune Haugbolle, "Naji Al-Ali and the Iconography of Arab Secularism," in Visual Culture in the Modern Middle East: Rhetoric of the Image, ed. Christiane Gruber and Sune Haugbolle, (Bloomington: Indiana University Press, 2013), 231-32.

50 Nur Masalha, "Naji al-Ali, Edward Said and Civil Liberation Theology in Palestine," Holy Land Studies 11, no. 2 (2012): 127-28.

$51 \quad$ Ibid., 128. 
Palestinian graffiti works also contain other iconic symbols such as the Palestinian flag and the Dome of the Rock. These symbols, along with the key symbol, highlight and reflect on the Palestinian experience of the Nakba. The picture in Figure-7, painted on the $64^{\text {th }}$ anniversary of the Nakba, ${ }^{52}$ provides a perspective into Palestinian political imagination, which is primarily predicated on the achievement of Palestinian rights and sovereignty over Jerusalem and the establishment of a sovereign Palestinian state. In the picture, these aspirations are indicated by the Dome of the Rock and flag images respectively. Appearing in the background, the eye gazing at the scene conveys the message that Palestinians still recall the memories that had once defined their lives and decades-long displacement has not affected their goal of reclaiming their historical rights.

The above graffiti works furnish an insight into the symbolic spectrum associated with Palestinian political aspirations. Viewing Israel as an exclusionary sovereign power that has caused geographical fragmentation of Palestine, Palestinian anti-occupation struggle aims to establish the Palestinian subject's political existence in an inclusionary sovereign space. During this struggle, Palestinians equip themselves with instruments of street art to increase the awareness-creating potential of their political messages. ${ }^{53}$ The visual space, therefore, provides Palestinians with a medium through which to articulate their aspirations.

Visual or otherwise, the overall Palestinian struggle rests essentially on undoing the hegemonic system which Israel has been seeking to consolidate in Palestine. Faced with the danger of the perpetuation of an occupation regime, the counter hegemonic struggle waged by Palestinians embodies within itself a strong political dimension, since, as Mouffe argues with reference to Gramsci, "Politics is always about the establishment, the reproduction, or the deconstruction of a hegemony, one that is always in relation to a potentially counter-hegemonic order." ${ }^{54}$ But, the fulfillment of counter hegemonic aspirations requires a collective effort by human

52 "Daily life in Gaza - in Pictures," The Guardian, June 8, 2012, https://www. theguardian.com/world/gallery/2012/jun/08/daily-life-gaza-in-pictures.

53 Rich Wiles, "Palestinian Graffiti: 'Tagging' Resistance," Al Jazeera, November 26, 2013, http://www.aljazeera.com/indepth/features/2013/11/palestinian-graffiti-taggingresistance-2013112015849368961.html.

54 Chantal Mouffe et al., "Every Form of Art Has a Political Dimension," Grey Room 2 (2001): 99. 
subjects. In her analysis of Gramsci's insights on how collectivity operates, Mouffe notes that "an historical act can only be performed by "collective man", and this presupposes the attainment of a "cultural-social" unity through which a multiplicity of dispersed wills, with heterogenous aims, are welded together." 55 This remark is illustrative of Gramsci's conceptualization of social existence, which is premised on the notion of "grouping which is that of all the social elements which share the same mode of thinking and acting." ${ }^{56}$ A product of this social reality, according to Gramsci, is "conformism" in the sense that "one is always mass-man or collective man." "'57

With that being said, since politics is ever present in settings populated by humans, any attempt by collective man to construct a hegemonic order is bound to provoke counter hegemonic tendencies, the reason being that "you can never have a complete, absolute, inclusive hegemony." 58 Seen through the micropolitical prism of Deleuze and Guattari, totalizing forces are destined to failure, because "There is always something that flows or flees, that escapes [...] the overcoding machine: things that are attributed to a "change in values," the youth, women, the mad, etc." ${ }^{59}$ In this view, there are always pattern-defying and unruly human subjects within entrenched power structures. In Deleuze's thinking, Palestinians also figure in the category of the insubordinate subject, ${ }^{60}$ which Deleuze "might elsewhere term a 'line of flight' - a mode of acting against the dominant system."

Palestinians' attempt to undermine the Israeli-imposed dominant system and inscribe their existence on a new political terrain informed by their own aspirations attests to the counter egemonic character of their struggle.

55 Chantal Mouffe, "Hegemony and Ideology in Gramsci," in Gramsci and Marxist Theory, ed. Chantal Mouffe (London: Routledge \& Kegan Paul, 1979), 191.

56 Antonio Gramsci, Selections from the Prison Notebooks of Antonio Gramsci, trans. Quintin Hoare and Geoffrey Nowell Smith (New York, International Publishers, 1971), 324.

57 Mouffe, "Hegemony and Ideology in Gramsci," 186.

58 Mouffe, "Every Form of Art Has a Political Dimension," 99.

59 Gilles Deleuze and Felix Guattari, A Thousand Plateaus, trans. Brian Massumi (London, Continuum, 2012), 216.

60 Gilles Deleuze, "Stones," Two Regimes of Madness: Texts and Interviews 1975-1995, ed. David Lapoujade (New York, Semiotext(e), 2007), 338-40.

${ }_{61}$ Kathryn Medien, "Palestine in Deleuze," Theory, Culture \& Society 36, no. 5 (2019): 13. 
The importance of artworks during this struggle is evidently clear, since, as the iconic symbols rooted in Palestinian street art tradition demonstrate, the visual space in occupied Palestine provides a medium for the process of meaning creation associated with Palestinian political imagination. Hence, in the overall struggle Palestinians have been waging against Israel, street artworks are best understood as "political artifacts," ${ }^{2}$ rather than as descriptive illustrations. It is also important to emphasize that Palestinian street art demonstrates the meaningless to discuss as to whether a piece of artwork is political or non-political. As Mouffe emphasizes,

One cannot make a distinction between political art and non-political art, because every form of artistic practice either contributes to the reproduction of the given common sense - and in that sense is political - or contributes to the deconstruction or critique of it. Every form of art has a political dimension. ${ }^{63}$

In Palestinian context, given that street art's overarching aim is to highlight Palestinian political aspirations and demands, the above-shown images serve as telling examples that demonstrate the inherent relationship between art and politics. Through street art, Palestinians essentially politicize the question of what it means to be living as a sovereignty-lacking nation. But street art also provides a means for presenting an alternative vision, one that is based on the collective indigenous existence of Palestinians.

\section{Visual Diversity in the Palestinian Street Art Scene}

Despite street art's proven effectiveness in the Palestinian anti-occupation struggle, it exhibits a remarkable degree of diversity in Palestinian settings. Due to ideological differences among Palestinian factions, street art scene is often populated by competing visual representations. Expectedly, signs and symbols suffusing street artworks reflect artists and groups' own politico-ideological orientations. For example, the Popular Front for the Liberation of Palestine (PFLP), which is a secular left-wing group and whose street art bears images of "workers, citizens and fighters,"

${ }^{62}$ Editorial Board, "Visual Culture and Remembering the Forgotten," Jerusalem Quarterly 61 (2015): 4.

63 Mouffe, "Every Form of Art Has a Political Dimension," 99.

${ }^{64}$ Charles Tripp, The Power and the People: Paths of Resistance in the Middle East (New York: Cambridge University Press, 2013), 266. 
use the image of Leila Khaled in their visuals. Moreover, the messages of PFLP often read "We salute the women of the intifada - PFLP." 65

Such messages are directed against conservative Palestinian movements that seek to promote religion-based gender stereotypes. For example, the message "Morals or else. . . -Hamas" ${ }^{" 66}$ indicates a religiously oriented discourse in street art, which is also manifest in religious groups' use of "Islamic symbols" and "Qur'anic quotations" ${ }^{67}$ in their visuals. To counter such representations, secular groups design and promote visual messages that portray Palestine as a nation rather than a religious community. For example, a graffito created by the Palestine Communist Party reads "Let the churches and mosques embrace each other in national unity." ${ }^{\prime 8}$ Such messages aim to emphasize the need to leave aside religious differences in the broad struggle of liberating Palestine. Furthermore, street art also furnishes rival political groups with a means to show their opposition to Palestinian Authority or to call for a national unity government between competing groups such as Hamas and Fatah. Examples include messages such as "Is this the government you elected?" or "Yes to National Unity." 69

Street artists have a common goal of contributing to the Palestinian liberation struggle by creating images that encourage Palestinians to maintain hope and resistance. But their depiction of Palestinian reality is informed by their own cultural-ideological formations. This leads to the creation of visuals that often clash with those created by other groups. And this is indicative of a deeper issue, which is the existence of internal schisms within the Palestinian collective body, an issue that undercuts the effectiveness of the Palestinian struggle. Graffiti works and textual elements accompanying them are simply illustrative of the existing intraPalestinian rivalries.

Street art in Palestine also draws support from international artists, for whom the erection of the Separation Wall in the West Bank presented an

65 Julie Peteet, "The Writing on the Walls: The Graffiti of the Intifada," Cultural Anthropology 11, no. 2 (1996): 154.

66 Ibid.

67 Tripp, The Power and the People, 265.

68 Peteet, "The Writing on the Walls," 154.

69 Larkin, “Jerusalem's Separation Wall and Global Message Board,” 152. 
opportunity to show their solidarity with Palestinians. Of all the foreign artists appearing in the Palestinian street art scene, British street artist Banksy merits special emphasis, as his aesthetic murals on the Separation Wall have attracted considerable international attention due to wide press coverage. ${ }^{70}$ Despite the international spotlight afforded to Banksy's works, they did not always resonate well with the local population, with some expressing their displeasure at "his aestheticization of their suffering." "71

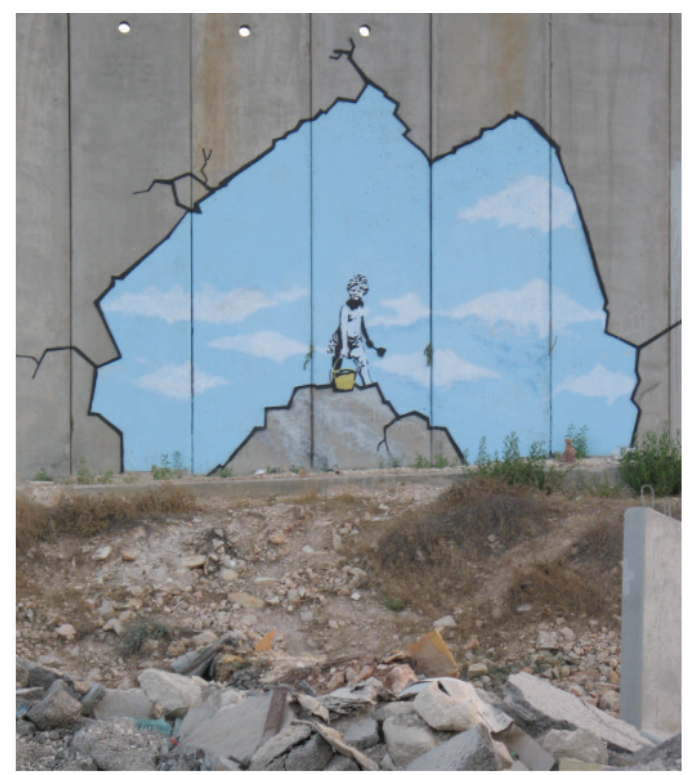

Figure-8: A Banksy mural on the Separation Wall

Image taken from: https://www.plastikmagazine.com/interview/banksy

For example, as recounted by Banksy, an old Palestinian man expressed displeasure at his picturesque murals on the Separation Wall by saying that "We don't want [the wall] to be beautiful. We hate this wall, go home."72 Some local artists have also taken a negative view of attempts to beatify the Separation Wall. As one artist put it,

70 William Parry, Against the Wall: Art of Resistance in Palestine (Chicago, Lawrence Hill Books, 2010), 6 .

71 Gould, "The Materiality of Resistance," 6.

72 Parry, Against the Wall, 10. 
I don't draw on the wall. I'm against anybody drawing (on it). [...] For me and for my ideas the Separation Wall is a very ugly wall, with a very ugly colour, it's a military colour. For us to draw, to put paint, and to put colour we will make the Wall different, we will make the Wall beautiful. It is not our job to make the Wall beautiful. ${ }^{73}$

Moreover, as Parry reports, some of Banksy's graffiti attracted angry reactions, such as when he drew a rat holding a slingshot with the aim of depicting an image of resistance. ${ }^{74}$ A similar reaction occurred, when Banksy painted an Israeli soldier checking the identity papers of a donkey. Although Banksy's intention was evidently to deride Israel's strict security measures, Palestinians took these two murals as an affront. These cases show how attempts at solidarity may backfire in the street art scene, when foreign artists are unaware of local sensitives.
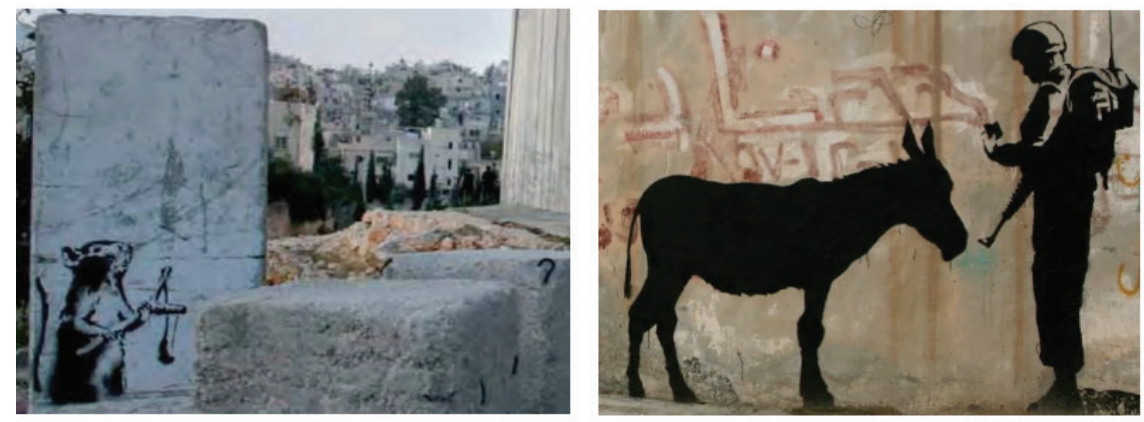

Figure-9: Two murals painted by Banksy in the West Bank

Images taken from: Parry, Against the Wall, 51; https://www.jweekly.com/2018/07/13/banksy-in-the-west-bankwhose-art-is-it-anyway/

The participation of foreign artists in the Palestinian street art scene begs the overall question of whether their works make the intended positive contribution to the Palestinian cause. If viewed in a positive light, foreign artists' presence in Palestine leads to a beneficial visual diversity, through which to appeal to audiences from different cultural backgrounds. Reaching out to greater number of people and raising their awareness about the Palestinian issue may potentially facilitate for Palestinians

73 Hugh Lovatt, "From National Resistance to Global Movement - An Intro to Palestinian Graffiti (PHOTOS)," Your Middle East, March 3, 2015, https:/yourmiddleeast. com/2015/03/03/from-national-resistance-to-global-movement-ae-an-intro-topalestinian-graffiti-photos/.

74 Parry, Against the Wall, 51. 
the process of finding networks of support internationally. ${ }^{75}$ As Ashley reminds, "during the first and second intifadas, [Palestinians] have turned toward transnational networks to try to find external powers that will help them challenge the occupation." ${ }^{.76}$ Given this fact, one can plausibly argue that visuals that find resonance beyond Palestine would afford Palestinians stronger connection with the outside world. As an acknowledgement of this, some locals have expressed a positive view of the Separation Wall's transformation into an attractive graffiti site. As stressed by a Jerusalemite Palestinian "The battle against the occupation has shifted from committees to media sites. The images of the [separation] wall often speak louder than politicians' voices."

One may also present a skeptical view regarding foreign artists' participation in the Palestinian street art scene. Analyzing Palestinian street art from the viewpoint of content and style, Gould describes the essence of Palestinian street art as being "allegorical and opaque", an example being the above-shown Leila Khaled's image (see Figure-1). ${ }^{78}$ "[B]rutal realities" Palestinians face in their everyday lives, in Gould's view, do not figure in the works of international artists, "who address a global Anglophone audience." ${ }^{\prime 79}$ Relatedly, analogies drawn with scenes such as "the Warsaw Ghetto and the Berlin Wall" are said to find little echo in Palestinian circles ${ }^{80}$ Although depictions created by foreign artists may attract more international attention than those by their local peers, aesthetic considerations are of secondary importance to the Palestinian artists, who are mainly concerned with providing visual support to the Palestinian struggle.

\footnotetext{
Larkin, "Jerusalem's Separation Wall and Global Message Board," 144.

Toenjes, "This Wall Speaks," 58.

Larkin, "Jerusalem's Separation Wall and Global Message Board," 141.

Gould, "The Materiality of Resistance," 14-15.

Ibid., 14.
}

80 Ibid., 13-14. 


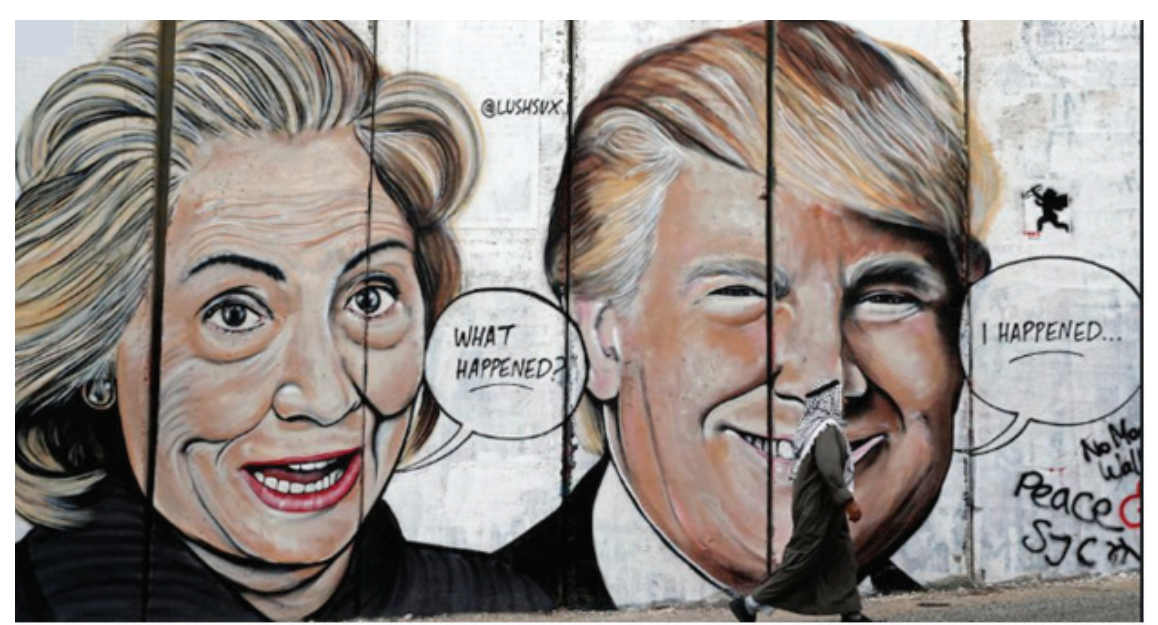

Figure-10: A mural painted by Lushsux on the Seperation Wall

Image taken from: https://www.trtworld.com/mea/protest-art-is-graffiti-on-the-west-bank-wall-losing-itsmeaning--11931

Related to this discussion, some authors argue that works produced by foreign artists may even create an adverse impact on the effectiveness of Palestinian visual resistance. Referring to the Separation Wall's becoming of a popular street art site, Larkin, for example, asserts that "While the highly publicized work of graffiti artists such as Banksy, Blu, and Sam engage a global audience and provide a subversive snapshot of local realities, they may in some ways obscure the complexity of everyday Palestinian responses to the wall." ${ }^{\prime 1}$ Irrelevant content found in the works of foreign artists lends support to those who are wary of outside participation. For example, some Palestinians think that the Separation Wall "had become a symbolic space for a stream of passing visitors in which to act out their fantasies, aesthetic and political." $" 82$

A case in point is the Australian artist Lushsux, who attracted criticism due to the thematic irrelevance of his works, which contain images of popular figures such as Donald Trump, Hillary Clinton and Mark Zuckerberg. A "Bethlehem resident Khader Jacaman" reacted to Lushsux's murals by saying that "there was "no relationship" between the art depicting Clinton

81 Larkin, “Jerusalem's Separation Wall and Global Message Board," 145.

82 Tripp, The Power and the People, 279. 
and Trump and the Palestinian cause." ${ }^{93}$ As a result of such graffiti pictures, sites such as the Separation Wall "risks becoming a street art gallery rather than actually politicising what it is about", as put by a British tourist visiting the site. ${ }^{84}$

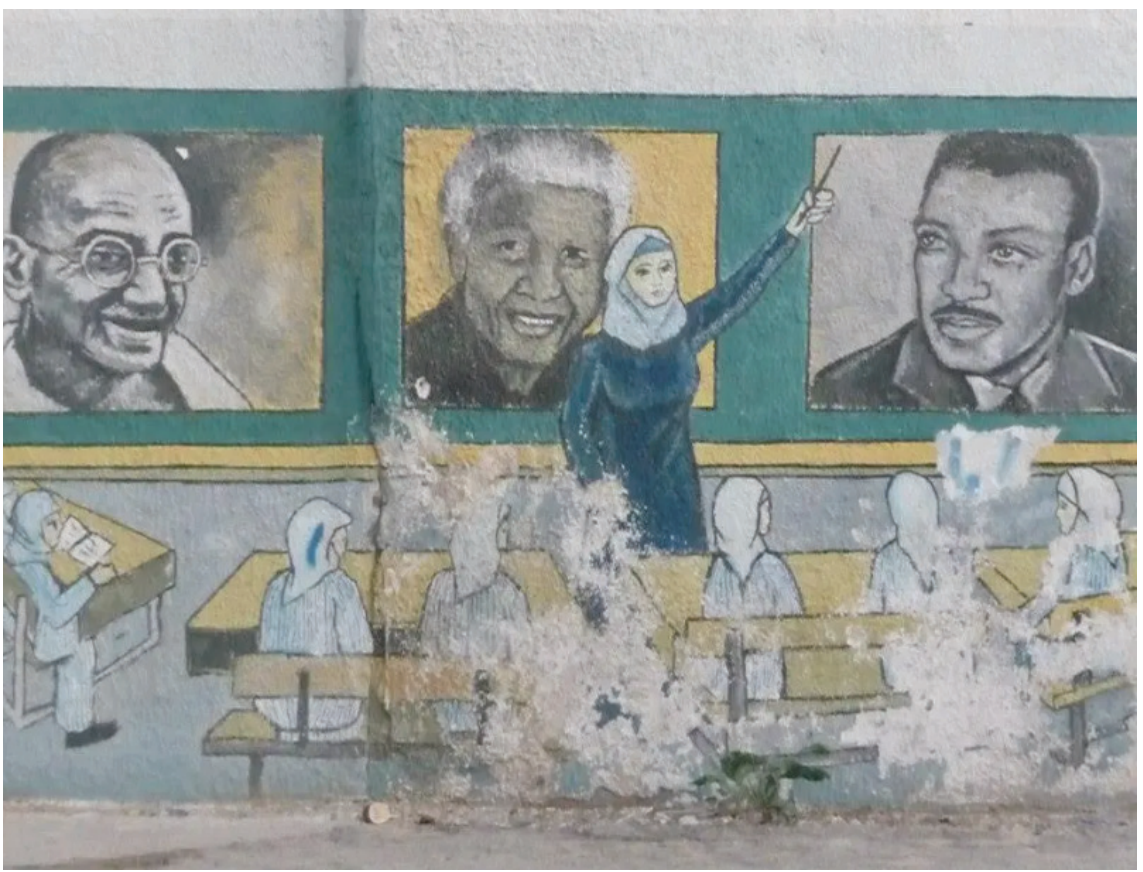

Figure-11: A Palestinian mural bearing the images of Mahatma Gandhi, Nelson Mandela and Martin Luther King

Image taken from: https://oralucero.wordpress.com/2012/12/18/gaza-street-art-rocks/\#jp-carousel-1428

Although irrelevant murals risk decontextualizing the meaning of Palestinian street art, symbolic localization could also create problems of its own. In response to views suggesting a more localized form of street art in Palestine, Jones convincingly argues that "particularizing the struggles of Palestine/Israel is part of the Zionist myth to justify settler colonialism." 85

83 Ben Said, "Protest Art: Is Graffiti on the West Bank Wall Losing Its Meaning?," TRT World, November 4, 2017, https://www.trtworld.com/mea/protest-art-is-graffiti-onthe-west-bank-wall-losing-its-meaning--11931.

$84 \quad$ Ibid.

85 Toenjes, "This Wall Speaks," 65. 
This view may help explain why some Palestinian artists integrated the images of world-renowned civil rights leaders into their works. The graffiti shown in Figure-11 is an example of this. The portrayal of a classroom that features a teacher explaining to her students Mahatma Gandhi, Nelson Mandela and Martin Luther King, is evidently an attempt by the Palestinian street artist to portray the Palestinian struggle as part of a broader freedom struggle. In a related vein, the fact that Palestinian intellectuals often draw analogies between Israel and other oppressive regimes (such as the pre-1994 South Africa) also demonstrates an inclination to broaden the analytical context, the purpose being to expose Israel's discriminatory treatment of Palestinians ${ }^{86}$ It can thus be maintained that isolating the Palestine issue in the visual realm by excluding international elements is a suboptimal strategy, if the objective is to highlight Israel's apartheid-like characteristic. Provided that external visual elements, whether incorporated by local or international artists, capture relevant commonalities between Palestine and other communities, they may help create a fruitful symbiosis in support of the Palestinian liberation narrative.

\section{Conclusion}

This manuscript has assessed the effectiveness of street art in the context of Palestinian struggle against Israel. I have shown in this work that art and politics in the history of Palestine are intrinsically related, with a discussion of how adherents of Zionism laid the institutional basis for the growth of an indigenous Jewish art in Palestine. Furthermore, I have illustrated that Israel has attempted to impede Palestinian artistic activity through security measures and sought to cultivate an image of the newly-settled territorial space in accordance with its own political vision. The counter hegemonic struggle waged by Palestinians through street art was argued to be a reaction against the Israeli-imposed politico-military reality.

Through a visual analysis of emblematic graffiti images that have been produced by Palestinian artists, I have shown that Palestinian images serve as a galvanizing force for the anti-occupation struggle. This was elaborated through an analysis of visuals such as the keffiyeh-clad woman and hand

86 Ari Shavit, “An Interview with Edward Said," Politics and Culture 3 (2000), https:// politicsandculture.org/2010/08/10/an-interview-with-edward-said-2/. 
on barbed wire graffiti images, which symbolize Palestinian determination to fight against occupation. Images with symbolic power, a concept borrowed from Bourdieu, were argued to be an effective instrument in provoking collective emotions, evoking a feeling of struggle and therefore in producing practitioners of resistance. Overall, street art was shown to be an empowering instrument due to its ability to instill in Palestinian collective consciousness a determination of resistance.

Secondly, street art's utility also lies in its ability to assist Palestinians in their bid to seek their inherent rights and political agency. This was discussed with reference to Palestinians' attempts to construct their own symbolic vocabulary through their incorporation of historically meaningful images in their artworks. To exemplify the point, the key symbol, Handala image and visuals bearing the Palestinian flag and the Dome of the Rock were analyzed. The fact that street artworks help politicize the question of Palestinian reality demonstrates the complementary relationship between art and politics. In articulating the point, two points were emphasized through a Mouffean prism: every artwork embodies within itself a political dimension and politics is a struggle between hegemonic and counter hegemonic forces. Seen through this prism, Palestinian street art's political character is evident, since it serves to contribute to the deconstruction of a hegemonic politico-military order, to reaffirm Palestinians' political existence and to project an alternative political imagination against the Israeli-enforced reality.

Lastly, as elaborated in this article, while there is a visual struggle against Israel, there is usually a parallel struggle underway among competing Palestinian groups with regards to whose illustrations should represent the Palestinian cause. By showing how political groups' (such as PFLP and Hamas') imbue their visuals with elements related to religion, gender and equality, the importance of cultural-ideological elements in Palestinian street art was emphasized. The content-wise diversity is important in that it is reflective of the absence of unity among Palestinian political factions. Palestinians also receive support from international artists, who seek to portray Palestinian life under occupation from their own artistic perspectives. Despite the positive contribution international artists try to make, as discussed with reference to Banksy, their depictions of the implications of occupation for Palestinians could run up against local sensitives. Cold reception given by Palestinians to Banksy's graffiti bearing animal images is indicative of this. 
Furthermore, foreign artists' graffiti pictures that bear no relevance to the Palestinian issue (such as the murals of popular figures) risk diluting the meaning of street art in Palestine. Opinions differ as to whether the internationalization of the visual scene weakens the effectiveness of Palestinian street art. As sought to be explained in this work with reference to certain images, Palestinians have proved adept at weaponizing street art by virtue of their skillful utilization of visuals and Arabic texts that project disobedience. Iconic signs and symbols associated with the Palestinian culture of resistance are effective tools in demonstrating the existence of the defiant Palestinian subject, which is of bedrock importance to the Palestinian struggle. With that being said, Palestinian visual resistance acquires greater effectiveness, if the content of street art is inclusive of international symbols such as the images of Mandela and Gandhi, since this helps generate the impression that Palestinians are a part of the global liberation struggle. Visual references to figures and events symbolizing liberation struggles serve to reinforce the belief that what Palestinians have been experiencing is not unique and like other victimized communities, they can also prevail in the liberation struggle they have been waging.

\section{Bibliography}

Achar, Gilbert. The Arabs and the Holocaust: The Arab-Israeli War of Narratives. London: Saqi Books, 2010.

Alatout, Samer. "Walls As Technologies of Government: The Double Construction of Geographies of Peace and Conflict in Israeli Politics, 2002-Present." Annals of the Association of American Geographers 99, no. 5 (2009): 956-68.

Boullata, Kamal. “Art under Siege”. Journal of Palestine Studies 33, no. 4 (2004): 70-84.

Boullata, Kamal. "Artists Re-Member Palestine in Beirut." Journal of Palestine Studies 32, no. 4 (2003): 22-38.

Bourdieu, Pierre. Language and Symbolic Power. Cambridge: Polity Press, 1991.

"Daily life in Gaza - in Pictures." The Guardian, June 8, 2012. https:// www.theguardian.com/world/gallery/2012/jun/08/daily-life-gaza-inpictures. 
De Certeau, Michel. The Practice of Everyday Life. Berkeley: University of California Press, 1984.

Deleuze, Gilles. "Stones." In Two Regimes of Madness: Texts and Interviews 1975-1995, edited by David Lapoujade, 338-40. New York: Semiotext(e), 2007.

Deleuze, Gilles, and Guattari, Felix. A Thousand Plateaus. Trans. Brian Massumi. London: Continuum, 2012.

Editorial Board. "Visual Culture and Remembering the Forgotten," Jerusalem Quarterly 61 (2015): 3-5.

Gal-Ezer, Miri. "The Third Space? From Modern Art Gallery to Modern Museum in Umm El-Fahem." In Memory and Ethnicity: Ethnic Museums in Israel and the Diaspora, edited by Emanuela Trevisan Semi, Dario Miccoli and Tudor Parfitt, 121-68. New Castle: Cambridge Scholars Publishing, 2013.

Gould, Rebecca. "The Materiality of Resistance: Israel's Apartheid Wall in an Age of Globalization," Social Text 118 32, no 1 (2014): 1-22.

Gramsci, Antonio. Selections from the Prison Notebooks of Antonio Gramsci. Trans. Quintin Hoare and Geoffrey Nowell Smith. New York: International Publishers, 1971.

Hasson, Nir. "First Monumental Zionist Work of Art' Uncovered in Jerusalem". Haaretz, October 15, 2012. https://www.haaretz.com/. premium-reviving-the-first-monumental-zionist-artwork-1.5192847.

Haugbolle, Sune, "Naji Al-Ali and the Iconography of Arab Secularism." In Visual Culture in the Modern Middle East: Rhetoric of the Image, edited by Christiane Gruber and Sune Haugbolle, 231-58. Bloomington: Indiana University Press, 2013.

Jannol, Hannah. "Banksy in the West Bank: Whose Art Is It Anyway?." The Jewish News of Northern California, July 13, 2018. https://www. jweekly.com/2018/07/13/banksy-in-the-west-bank-whose-art-is-itanyway/.

Khalili, Laleh. Heroes and Martyrs of Palestine: The Politics of National Commemoration. New York: Cambridge University Press, 2007

Larkin, Craig. "Jerusalem's Separation Wall and Global Message Board: Graffiti, Murals, and the Art of Sumud." The Arab Studies Journal 22, no. 1 (Special Issue: Cultures of Resistance, 2014): 134-69. 
Lovatt, Hugh. "From National Resistance to Global Movement - An Intro to Palestinian Graffiti (PHOTOS)." Your Middle East, March 3, 2015, https://yourmiddleeast.com/2015/03/03/from-national-resistance-toglobal-movement-ae-an-intro-to-palestinian-graffiti-photos/.

Mac Greigair, Gawan. "Nazareth's Mystery Mural as an Emblem of Palestinian Resistance." Al Araby, November 2, 2107. https://www. alaraby.co.uk/english/indepth/2017/11/13/nazareths-mystery-muralas-an-emblem-of-palestinian-resistance.

Manor, Dalia. Art in Zion: The Genesis of Modern National Art in Jewish Palestine. London: Routledge, 2005.

Masalha, Nur. "Naji al-Ali, Edward Said and Civil Liberation Theology in Palestine." Holy Land Studies 11, no. 2 (2012): 109-34.

Massad, Joseph. "Permission to Paint: Palestinian Art and the Colonial Encounter." Art of Journal 66, no. 3 (2007): 126-33.

Medien, Kathryn. "Palestine in Deleuze." Theory, Culture \& Society 36, no. 5 (2019): 1-22.

Mohamad, Husam. "President George W. Bush's Legacy on the IsraeliPalestinian "Peace Process." Journal of International and Area Studies 22, no. 1 (2015): 79-92.

Mouffe, Chantal. "Hegemony and Ideology in Gramsci." In Gramsci and Marxist Theory, edited by Chantal Mouffe, 168-204. London: Routledge \& Kegan Paul, 1979.

Mouffe, Chantal et al. "Every Form of Art Has a Political Dimension," Grey Room 2 (2001): 99-125.

Musleh, Maath. "Taking Back Palestine's Streets: Exclusive Interview with Underground Jerusalem Graffiti Artist." Electronic Intifada, August 29, 2012, https://electronicintifada.net/content/taking-back-palestinesstreets-exclusive-interview-underground-jerusalem-graffiti-artist.

"Palestinians to Netanyahu: You Will Never Break Our Will." The Jerusalem Post, September 11, 2019. https://www.jpost.com/Israel-News/ Palestinians-to-Netanyahu-You-will-never-break-our-will-601398.

Parry, William. Against the Wall: Art of Resistance in Palestine. Chicago: Lawrence Hill Books, 2010. 
Perlmutter, David D. "Photojournalism and Foreign Affairs," Orbis 49, no 1 (2005): 109-22.

Peteet, Julie. "The Writing on the Walls: The Graffiti of the Intifada." Cultural Anthropology 11, no. 2 (1996): 139-59.

Saad, Rhonda A. "Palestinian Art: From 1850 to the Present by Kamal Boullata." The Arab Studies Journal 18, no. 1 (2010): 330-33.

Said, Ben. "Protest Art: Is Graffiti on the West Bank Wall Losing Its Meaning?." TRT World, November 4, 2017. https://www.trtworld. $\mathrm{com} / \mathrm{mea} /$ protest-art-is-graffiti-on-the-west-bank-wall-losing-itsmeaning--11931.

Segev, Tom. One Palestine, Complete. Trans. Haim Watzman. New York: Metropolitan Books, 2000.

Shapiro, Michael J. Methods and Nations: Cultural Governance and the Indigenous Subject. London: Routledge, 2004.

Shlaim, Avi. The Iron Wall: Israel and the Arab World (Updated and Expanded). New York: W. W. Norton \& Company, Kindle Edition, 2014.

Shavit, Ari. "An Interview with Edward Said," Politics and Culture 3 (2000), https://politicsandculture.org/2010/08/10/an-interview-withedward-said-2/.

Sternhell, Zeev. Nationalism, Socialism, and the Making of the Jewish State. Trans. David Maisel. Princeton: Princeton University Press, 1998.

Toenjes, Ashley. "This Wall Speaks: Graffiti and Transnational Networks in Palestine." Jerusalem Quarterly 61, (2015): 55-68.

Thrall, Nathan. The Only Language They Understand: Forcing Compromise in Israel and Palestine. New York: Metropolitan Books, Kindle Edition, 2017.

Tripp, Charles. The Power and the People: Paths of Resistance in the Middle East. New York: Cambridge University Press, 2013.

Weizman, Eyal. Hollow Land: Israel's Architecture of Occupation. London: Verso, 2007. 
Wiles, Rich. "Palestinian Graffiti: 'Tagging' Resistance." Al Jazeera, November 26, 2013, http://www.aljazeera.com/indepth/features/2013/ 11/palestinian-graffiti-tagging-resistance-20131120158 President George W. Bush's Legacy on the Israeli-Palestinian "Peace Process"

Williams, Lee. "Intifada: What Is It - and What Does a Third Uprising Mean for the Region?." The Independent, October 9, 2015, https://www. independent.co.uk/news/world/what-exactly-is-an-infitada-a6688091. html. 
